\title{
Analysis of The Effect of Changes in Biological Education Student Routine During Covid-19 Pandemic on Learning Spirit and Understanding Lecture Materials
}

\author{
iwanyusup20@gmail.com ${ }^{\text {a*, Sumiyati Sa'adaha }}{ }^{\text {, }}$, Milla Listiawatia ${ }^{\text {, Idad Suhada }}{ }^{\mathrm{a}}$ \\ ${ }^{a}$ Fakultas Tarbiyah dan Keguruan, UIN Sunan Gunung Djati, Bandung, Indonesia \\ oktianfajarnugroho@gmail.com*; umiabio1@uinsgd.ac.id; millalistiawati@gmail.com; \\ suhadaidad@yahoo.co.id \\ *Corresponding author
}

\begin{tabular}{l} 
Article Info \\
\hline Article history: \\
Received Aug 23, 2021 \\
Revised Oct 28, 2021 \\
Accepted Oct 28, 2021 \\
\hline
\end{tabular}

Keywords:

Routines

Responses

Pandemics

\begin{abstract}
Online and offline learning will have a different impact on the level of understanding of students about learning materials. In this study the researchers tried to find out how the learning activities of Biology Education students at UIN Sunan Gunung Djati Bandung during the pandemic were related to changes in routine during the pandemic which affected the enthusiasm for learning and understanding of lecture material during the pandemic compared to before the pandemic. This research uses descriptive research method because in its implementation it includes data, analysis and interpretation of the meaning and data obtained. This study uses a questionnaire, the list of questions is structured in the form of multiple-choice questions and open questions (multiple choice questions and open questions). This method is used to obtain data about the effect of changes in the routine of Biology Education students during the pandemic on learning enthusiasm and understanding the material from respondents. Biology education students admit that there have been significant changes in their routine during the pandemic period. These changes have an impact on student learning activities.
\end{abstract}

This is an open access article under the $\underline{C C B Y-S A}$ license.

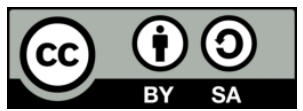

\section{Introduction}

Education is a conscious and planned effort by someone to realize an effective learning process with the aim of educating students in developing their potential. Through education there is a learning process for students which is a process of change in the human personality, and these changes are shown in the form of increasing the quality and quantity of behavior such as increasing skills, knowledge, attitudes, habits, understanding, skills, thinking power, and other abilities. Hakim, 2005: 1).

Today, there is a problem that makes student learning activities change due to the covid19 pandemic, so learning cannot be taken off must be carried out online (in the network). But of course, these changes will not be easily implemented by actors in the world of education, especially students. Starting from the constraints of limited infrastructure, to the decreased enthusiasm for learning of students due to other obstacles that occur because 
learning is carried out online. These problems can hinder the achievement of the expected goals (Cahyani, et al: 124).

Good learning, of course, begins with a good spirit of learning, before learning activities are carried out, the level of student enthusiasm for learning triggers the effectiveness of learning. In this case, online learning will have an impact on morale

students learn, given the face-to-face learning culture that is still inherent in themselves, so it is not uncommon during online learning many students feel bored or bored which has an impact on learning outcomes that tend to not be as expected (C Briliannur, 2020: 36).

Of course, online and offline learning will have a different impact on the level of students' understanding of the learning material. In offline learning, it can be designed in such a way that it can produce appropriate learning that has an impact on the level of students' understanding of the material presented in learning (Nurhayati, 2020: 145).

However, due to a pandemic that requires online learning activities, learning activities have changed in their implementation, so that it will result in a different level of understanding of learning materials from offline learning. In this study, researchers tried to find out how the learning activities of Biology Education students at UIN Sunan Gunung Djati Bandung during the pandemic were related to changes in routine during the pandemic that affected the enthusiasm for learning and understanding of lecture material during the pandemic compared to before the pandemic.

\section{Method}

This study uses descriptive research methods. The data obtained came from 31 respondents of Biology Education students of UIN Sunan Gunung Djati Bandung from various generations. Questionnaires are distributed to respondents via google form, then the data is analyzed to describe the level of influence of student routines during the pandemic period on lectures. This research is structured as inductive research that is looking for and collecting data in the field with the aim of knowing the factors, elements of form, and a nature of phenomena in society. (Nazir, 1998: 51).

The method of data collection is one aspect that plays a role in the smoothness and success of a research. We use the Questionnaire or Questionnaire method. According to (Mardalis: 2008: 66), a questionnaire or questionnaire is a technique of collecting data through forms containing written questions to a person or group of people to get answers or responses and information needed by researchers. questionnaire, the list of questions is structured in the form of multiple-choice questions and open questions. This method is used to obtain data on the effect of changes in the routines of Biology Education students during the pandemic on the enthusiasm for learning and understanding the material from the respondents. The characteristics of the respondents are students who are conducting online lectures, so it is hoped that the responses they give are real and experienced directly by students.

The data that has been collected is then processed. All data collected is then presented in a nice and tidy arrangement. Included in the data processing activity is calculating the frequency of the influence of interior design on the public's interest in visiting based on the result data. The questionnaire was then processed to obtain a percentage value. The stages of data processing are:

1. Editing. All the list of questions in the form, the questionnaire data that was collected was then checked first and grouped. 
2. Data Compilation and Analysis Data compilation and calculation done manually using a computer. (Singarimbun, 1994: 248).

The stages of data processing the results of this study are as follows:

1. Check for completeness of answers. At this stage the data obtained are re-examined to find answers from incomplete questionnaires.

2. Next is to analyze a problem that interferes with the learning process during a pandemic or the frequency of each answer in the questionnaire.

3. Summarize what problems often occur and are experienced by respondents.

Table 1. Semester/class of respondents

\begin{tabular}{cccc}
\hline No & Class & Amount & Percentage \\
\hline 1 & $1 \mathrm{~A}$ & 1 & $3.3 \%$ \\
2 & $1 \mathrm{~B}$ & - & - \\
3 & $1 \mathrm{C}$ & - & - \\
4 & $3 \mathrm{~A}$ & 2 & $6.7 \%$ \\
5 & $3 \mathrm{~B}$ & 9 & $30 \%$ \\
6 & $3 \mathrm{C}$ & 5 & $16.7 \%$ \\
7 & $5 \mathrm{~A}$ & 1 & $3.3 \%$ \\
8 & $5 \mathrm{~B}$ & 1 & $3.3 \%$ \\
9 & $5 \mathrm{C}$ & 1 & $3.3 \%$ \\
10 & $7 \mathrm{~A}$ & 4 & $13.3 \%$ \\
11 & $7 \mathrm{~B}$ & 6 & $20 \%$ \\
12 & $7 \mathrm{C}$ & 1 & $3.3 \%$ \\
\hline
\end{tabular}

\section{Results and Discussion}

The following is a table of observational data regarding changes in student routines during the pandemic.

Rutine changes during the COVID-19 Pandemic

Table 2.

\begin{tabular}{|c|c|c|c|c|c|c|c|}
\hline \multicolumn{8}{|c|}{ During the COVID-19 pandemic, my sleep time is the same as before the pandemic. } \\
\hline \multicolumn{2}{|c|}{ Do not agree } & \multicolumn{2}{|c|}{ Disagree } & \multicolumn{2}{|c|}{ Agree } & \multicolumn{2}{|c|}{ Strongly agree } \\
\hline $\begin{array}{c}\text { Amount } \\
2\end{array}$ & $\begin{array}{c}\text { Percentage } \\
26.7 \%\end{array}$ & $\begin{array}{c}\text { Amount } \\
13\end{array}$ & $\begin{array}{c}\text { Percentage } \\
43.3 \%\end{array}$ & $\begin{array}{c}\text { Amount } \\
7 \\
\end{array}$ & $\begin{array}{c}\text { Percentage } \\
23.3 \%\end{array}$ & $\begin{array}{c}\text { Amount } \\
8 \\
\end{array}$ & $\begin{array}{c}\text { Percentage } \\
6.7 \%\end{array}$ \\
\hline \multicolumn{8}{|c|}{ Table 3.} \\
\hline \multicolumn{8}{|c|}{ Sleep time turns longer during the covid-19 pandemic } \\
\hline \multicolumn{2}{|c|}{ Do not agree } & \multicolumn{2}{|c|}{ Disagree } & \multicolumn{2}{|c|}{ Agree } & \multicolumn{2}{|c|}{ Strongly agree } \\
\hline $\begin{array}{c}\text { Amount } \\
4 \\
\end{array}$ & $\begin{array}{c}\text { Percentage } \\
13.3 \% \\
\end{array}$ & $\begin{array}{c}\text { Amount } \\
16 \\
\end{array}$ & $\begin{array}{c}\text { Percentage } \\
53.3 \% \\
\end{array}$ & $\begin{array}{c}\text { Amount } \\
8 \\
\end{array}$ & $\begin{array}{c}\text { Percentage } \\
26.7 \% \\
\end{array}$ & $\begin{array}{c}\text { Amount } \\
2 \\
\end{array}$ & $\begin{array}{c}\text { Percentage } \\
6.7 \% \\
\end{array}$ \\
\hline \multicolumn{8}{|c|}{ Table 4.} \\
\hline \multicolumn{8}{|c|}{ During the covid-19 pandemic I prayed more on time before the pandemic. } \\
\hline \multicolumn{2}{|c|}{ Do not agree } & \multicolumn{2}{|c|}{ Disagree } & \multicolumn{2}{|c|}{ Agree } & \multicolumn{2}{|c|}{ Strongly agree } \\
\hline $\begin{array}{c}\text { Amount } \\
-\end{array}$ & $\begin{array}{c}\text { Percentage } \\
-\end{array}$ & $\begin{array}{c}\text { Amount } \\
7 \\
\end{array}$ & $\begin{array}{c}\text { Percentage } \\
23.3 \% \\
\end{array}$ & $\begin{array}{c}\text { Amount } \\
20\end{array}$ & $\begin{array}{c}\text { Percentage } \\
66.7 \% \\
\end{array}$ & $\begin{array}{c}\text { Amount } \\
3 \\
\end{array}$ & $\begin{array}{c}\text { Percentage } \\
10 \% \\
\end{array}$ \\
\hline \multicolumn{8}{|c|}{ Table 5.} \\
\hline \multicolumn{8}{|c|}{ I am more diligent in carrying out sunnah prayers during the covid-19 pandemic } \\
\hline \multicolumn{2}{|c|}{ Do not agree } & \multicolumn{2}{|c|}{ Disagree } & \multicolumn{2}{|c|}{ Agree } & \multicolumn{2}{|c|}{ Strongly agree } \\
\hline $\begin{array}{c}\text { Amount } \\
1 \\
\end{array}$ & $\begin{array}{c}\text { Percentage } \\
3.3 \% \\
\end{array}$ & $\begin{array}{c}\text { Amount } \\
14\end{array}$ & $\begin{array}{c}\text { Percentage } \\
46.7 \%\end{array}$ & $\begin{array}{c}\text { Amount } \\
12 \\
\end{array}$ & $\begin{array}{c}\text { Percentage } \\
40 \%\end{array}$ & $\begin{array}{c}\text { Amount } \\
3 \\
\end{array}$ & $\begin{array}{c}\text { Percentage } \\
10 \% \\
\end{array}$ \\
\hline \multicolumn{8}{|c|}{ Table 6.} \\
\hline \multicolumn{8}{|c|}{ Spend more time during the day working than staying at home } \\
\hline Do 1 & agree & & gree & & & Stron & agree \\
\hline
\end{tabular}




\begin{tabular}{|c|c|c|c|c|c|c|c|}
\hline $\begin{array}{c}\text { Amount } \\
8 \\
\end{array}$ & $\begin{array}{c}\text { Percentage } \\
26.7 \%\end{array}$ & $\begin{array}{c}\text { Amount } \\
12\end{array}$ & $\begin{array}{c}\text { Percentage } \\
40 \%\end{array}$ & $\begin{array}{c}\text { Amount } \\
8 \\
\end{array}$ & $\begin{array}{c}\text { Percentage } \\
26.7 \%\end{array}$ & $\begin{array}{c}\text { Amount } \\
2\end{array}$ & $\begin{array}{c}\text { Percentage } \\
6.7 \%\end{array}$ \\
\hline \multicolumn{8}{|c|}{ Table 7.} \\
\hline \multicolumn{8}{|c|}{ Playing more social media and games than studying } \\
\hline \multicolumn{2}{|c|}{ Do not agree } & \multicolumn{2}{|c|}{ Disagree } & \multicolumn{2}{|c|}{ Agree } & \multicolumn{2}{|c|}{ Strongly agree } \\
\hline $\begin{array}{c}\text { Amount } \\
4\end{array}$ & $\begin{array}{c}\text { Percentage } \\
13.3 \%\end{array}$ & $\begin{array}{c}\text { Amount } \\
9\end{array}$ & $\begin{array}{c}\text { Percentage } \\
30 \%\end{array}$ & $\begin{array}{c}\text { Amount } \\
13\end{array}$ & $\begin{array}{c}\text { Percentage } \\
43.3 \%\end{array}$ & $\underset{4}{\text { Amount }}$ & $\begin{array}{c}\text { Percentage } \\
13.3 \%\end{array}$ \\
\hline \multicolumn{8}{|c|}{ Table 8.} \\
\hline \multicolumn{8}{|c|}{ Leave online learning to do other activities. } \\
\hline \multicolumn{2}{|c|}{ Do not agree } & \multicolumn{2}{|c|}{ Disagree } & \multicolumn{2}{|c|}{ Agree } & \multicolumn{2}{|c|}{ Strongly agree } \\
\hline $\begin{array}{c}\text { Amount } \\
9\end{array}$ & $\begin{array}{c}\text { Percentage } \\
30 \%\end{array}$ & $\begin{array}{c}\text { Amount } \\
14\end{array}$ & $\begin{array}{c}\text { Percentage } \\
46.7 \%\end{array}$ & $\begin{array}{c}\text { Amount } \\
5\end{array}$ & $\begin{array}{c}\text { Percentage } \\
16.7 \%\end{array}$ & $\begin{array}{c}\text { Amount } \\
2\end{array}$ & $\begin{array}{c}\text { Percentage } \\
6.7 \%\end{array}$ \\
\hline
\end{tabular}

Thus, the results obtained that biology education students taken from (31) respondents experienced a change in routine since the Covid-19 pandemic. These changes involve religious activities and daily activities that have better and worse effects than before the Covid-19 pandemic.

\section{Enthusiasm to learn and understand the lecture material}

Table 9.

\begin{tabular}{|c|c|c|c|c|c|c|c|}
\hline \multicolumn{8}{|c|}{ I am very enthusiastic every time I start studying } \\
\hline \multicolumn{2}{|c|}{ Do not agree } & \multicolumn{2}{|c|}{ Disagree } & \multicolumn{2}{|c|}{ Agree } & \multicolumn{2}{|c|}{ Strongly agree } \\
\hline $\begin{array}{c}\text { Amount } \\
1\end{array}$ & $\begin{array}{c}\text { Percentage } \\
3.3 \%\end{array}$ & $\begin{array}{c}\text { Amount } \\
13\end{array}$ & $\begin{array}{c}\text { Percentage } \\
43.3 \%\end{array}$ & $\begin{array}{c}\text { Amount } \\
13\end{array}$ & $\begin{array}{c}\text { Percentage } \\
43.4 \%\end{array}$ & $\begin{array}{c}\text { Amount } \\
3\end{array}$ & $\begin{array}{c}\text { Percentage } \\
10 \%\end{array}$ \\
\hline \multicolumn{8}{|c|}{ Table 10.} \\
\hline \multicolumn{8}{|c|}{ I work on assignments with enthusiasm so that they can be submitted on time } \\
\hline \multicolumn{2}{|c|}{ Do not agree } & \multicolumn{2}{|c|}{ Disagree } & \multicolumn{2}{|c|}{ Agree } & \multicolumn{2}{|c|}{ Strongly agree } \\
\hline $\begin{array}{c}\text { Amount } \\
1\end{array}$ & $\begin{array}{c}\text { Percentage } \\
3.3 \%\end{array}$ & $\begin{array}{c}\text { Amount } \\
10\end{array}$ & $\begin{array}{c}\text { Percentage } \\
33.3 \%\end{array}$ & $\begin{array}{c}\text { Amount } \\
16\end{array}$ & $\begin{array}{c}\text { Percentage } \\
53.3 \%\end{array}$ & $\begin{array}{c}\text { Amount } \\
3\end{array}$ & $\begin{array}{c}\text { Percentage } \\
10 \%\end{array}$ \\
\hline \multicolumn{8}{|c|}{ Table 11.} \\
\hline \multicolumn{8}{|c|}{ I am very focused on following online learning } \\
\hline \multicolumn{2}{|c|}{ Do not agree } & \multicolumn{2}{|c|}{ Disagree } & \multicolumn{2}{|c|}{ Agree } & \multicolumn{2}{|c|}{ Strongly agree } \\
\hline$\underset{4}{\text { Amount }}$ & $\begin{array}{c}\text { Percentage } \\
13.3 \%\end{array}$ & $\begin{array}{c}\text { Amount } \\
19\end{array}$ & $\begin{array}{c}\text { Percentage } \\
63.3 \%\end{array}$ & $\begin{array}{c}\text { Amount } \\
7\end{array}$ & $\begin{array}{c}\text { Percentage } \\
33.3 \%\end{array}$ & Amount & Percentage \\
\hline
\end{tabular}

Table 12.

\begin{tabular}{|c|c|c|c|c|c|c|c|}
\hline \multicolumn{8}{|c|}{ During online learning, it is easier for me to understand the material explained by the lecturer } \\
\hline \multicolumn{2}{|c|}{ Do not agree } & \multicolumn{2}{|c|}{ Disagree } & \multicolumn{2}{|c|}{ Agree } & \multicolumn{2}{|c|}{ Strongly agree } \\
\hline $\begin{array}{c}\text { Amount } \\
11\end{array}$ & $\begin{array}{c}\text { Percentage } \\
36.7 \%\end{array}$ & $\begin{array}{c}\text { Amount } \\
15\end{array}$ & $\begin{array}{c}\text { Percentage } \\
50 \%\end{array}$ & $\begin{array}{c}\text { Amount } \\
2 \\
\end{array}$ & $\begin{array}{c}\text { Percentage } \\
6.7 \%\end{array}$ & $\begin{array}{c}\text { Amount } \\
2\end{array}$ & $\begin{array}{c}\text { Percentage } \\
6.7 \%\end{array}$ \\
\hline \multicolumn{8}{|c|}{ Table 13.} \\
\hline \multicolumn{8}{|c|}{ I am more enthusiastic about working on independent practicums than with groups during the pandemic. } \\
\hline \multicolumn{2}{|c|}{ Do not agree } & \multicolumn{2}{|c|}{ Disagree } & \multicolumn{2}{|c|}{ Agree } & \multicolumn{2}{|c|}{ Strongly agree } \\
\hline $\begin{array}{c}\text { Amount } \\
13\end{array}$ & $\begin{array}{c}\text { Percentage } \\
43.3 \%\end{array}$ & $\begin{array}{c}\text { Amount } \\
9\end{array}$ & $\begin{array}{c}\text { Percentage } \\
30 \%\end{array}$ & $\begin{array}{c}\text { Amount } \\
6\end{array}$ & $\begin{array}{c}\text { Percentage } \\
20 \%\end{array}$ & $\begin{array}{c}\text { Amount } \\
2\end{array}$ & $\begin{array}{c}\text { Percentage } \\
6.7 \%\end{array}$ \\
\hline
\end{tabular}

Table 14.

I find it difficult to understand practical procedures during online learning

\begin{tabular}{cccccccc}
\hline \multicolumn{2}{c}{ I find it difficult to understand practical procedures during online learning } \\
\hline \multicolumn{1}{c}{ Do not agree } & \multicolumn{2}{c}{ Disagree } & \multicolumn{2}{c}{ Agree } & \multicolumn{2}{c}{ Strongly agree } \\
Amount & Percentage & Amount & Percentage & Amount & Percentage & Amount & Percentage \\
1 & $3.3 \%$ & 3 & $10 \%$ & 17 & $56.7 \%$ & 9 & $30 \%$ \\
\hline \multicolumn{7}{c}{ Table 15. } \\
\hline
\end{tabular}

I am enthusiastic about participating in online learning but often have network problems

$\begin{array}{llll}\text { Do not agree } & \text { Disagree } & \text { Agree } & \text { Strongly agree }\end{array}$

Amount Percentage Amount Percentage Amount Percentage Amount Percentage




\begin{tabular}{|c|c|c|c|c|c|c|c|}
\hline 5 & $16.7 \%$ & 6 & $20 \%$ & 14 & $46.7 \%$ & 5 & $16.7 \%$ \\
\hline \multicolumn{8}{|c|}{ Table 16.} \\
\hline \multicolumn{8}{|c|}{ I find it very easy to do UTS because I understand the material presented online } \\
\hline \multicolumn{2}{|c|}{ Do not agree } & \multicolumn{2}{|c|}{ Disagree } & \multicolumn{2}{|c|}{ Agree } & \multicolumn{2}{|c|}{ Strongly agree } \\
\hline $\begin{array}{c}\text { Amount } \\
7\end{array}$ & $\begin{array}{c}\text { Percentage } \\
23.3 \%\end{array}$ & $\begin{array}{c}\text { Amount } \\
18\end{array}$ & $\begin{array}{c}\text { Percentage } \\
60 \%\end{array}$ & $\begin{array}{c}\text { Amount } \\
5\end{array}$ & $\begin{array}{c}\text { Percentage } \\
16.7 \%\end{array}$ & $\begin{array}{c}\text { Amount } \\
-\end{array}$ & $\begin{array}{c}\text { Percentage } \\
-\end{array}$ \\
\hline
\end{tabular}

Based on the table above, it can be concluded that biology education students represented by 30 respondents experienced advantages and disadvantages in conducting online learning activities. Some respondents found it difficult to conduct online learning due to network limitations in their respective places of residence, but it did not become an obstacle to submitting assignments on time. And keep trying to focus on online learning even though they still don't understand the material being studied and still try their best to carry out the upcoming midterm and final exam.

The result data shows that there is a change in routine caused by the pandemic, where almost every activity is carried out at home to prevent the spread of the pandemic increasing. This change in routine certainly affects the learning activities of Education students Biology. According to Saleh in Argaheni (2020: 104), the government made a special policy for students from kindergarten to university to maintain a distance to reduce the spread of the pandemic. So that the implementation of teaching and learning activities is carried out at home and interacts through various technological devices to support teaching and learning obligations.

Based on the results table, $43 \%$ of the 30 respondents did not agree with the statement that sleep time is the same as before the pandemic, then $53 \%$ of respondents said they did not agree with the statement that sleep time became longer during the pandemic. In the first statement, the number of respondents whose sleep time is not the same as before the pandemic means that the change in sleep time is shorter. This is because the first and second statements have a relationship if the percentage of both is higher in the "less agree" plus "disagree" option compared to the percentage in the "agree" and "strongly agree" options, meaning that the change in sleep time in the first statement is shorter sleep time. vice versa. According to Haryanti (2020: 1113),

In the third statement, the highest percentage is $66.7 \%$ in the "agree" answer, which means that the respondents agree that the implementation of obligatory prayers is more timely than before the pandemic. While in the fourth statement, the highest percentage is $46.7 \%$ in the "disagree" answer, meaning that during the pandemic it does not make respondents more diligent in carrying out sunnah prayers. But it differs slightly from the second highest percentage, which is $40 \%$ in the agreed answer, meaning that not a few of the sunnah prayers have become more diligent than before the pandemic.

Learning that is carried out online makes its implementation not always done at home. As long as there is internet access and adequate devices, it can be accessed anytime and anywhere. Based on the result data, $40 \%$ of respondents answered that they did not agree that during the pandemic they worked more compared to staying at home, then $26.7 \%$ disagree, $26.7 \%$ agree, and the rest strongly agree. Although the percentages who answered agree and strongly agree were smaller than those who did not agree and disagree, it means that there are some students who do other activities outside of lectures such as work and others.

In the eighth statement, the percentage of choices agree and strongly agree is greater than less agree and disagree. So, about 17 out of 30 people agree that they use their 
smartphone more often to play social media and games than to study, this could be because respondents feel bored while studying online, so to get rid of boredom a little, they switch them to playing social media or games.

Based on the result data in the ninth statement, about 23 people out of 30 people disagree and disagree about the statement that respondents leave online learning to do other activities. This shows that there are still many students who still follow online learning well by not leaving them to do other activities. According to Sari, et al (2020: 157), online learning allows students to take part in learning activities from home, access learning activities without having to go to school, so that schools become quiet without crowds that have the potential to become a place for the spread of a pandemic. However, in this way, it provides opportunities for students to ignore learning activities,

In the next questionnaire about the spirit of learning and understanding of lecture material, there are 8 statements. Based on the result data, in the first statement there was a draw on the choice of agreeing and disagreeing, namely at a percentage of $43.3 \%$, meaning that around 13 people chose to agree and disagree that they were very enthusiastic every time they started lectures during the pandemic. While 3 people answered agree, and 1 person answered disagree. According to Jariyah and Tyastirin (2020: 192), there are several obstacles that cause a lack of enthusiasm for students in online learning such as a lack of student understanding due to explanations that cannot be fully absorbed by students because direct delivery of material is always better and easier to accept than through online.

Meanwhile, in the next statement, "I do my assignment with enthusiasm so that it can be collected on time", about 16 people answered agree. Even though when viewed from the lack of enthusiasm for starting lectures, when working on assignments the students are still enthusiastic about doing it, so this result can be said to be contrary to the data in the previous statement that the enthusiasm of students in participating in online learning is lacking. High motivation is needed to be able to do assignments which of course become a burden that must be completed by students. According to Cahyani, et al (2020: 138), the persistence of students in doing the tasks given requires high motivation. Learning motivation is needed by every student to be able to undergo learning activities, either when learning is on schedule or off schedule such as doing assignments.

Then in the next statement about focusing on participating in online learning, 19 people answered that they did not agree. This means that many students feel that they cannot focus on participating in online learning which can be caused by various factors, plus when at home there are more other activities that may have to be done such as helping parents and other activities at home. In line with the results of research by Cahyani, et al (2020: 137), the cause of the difficulty of students focusing on learning is a family environment that is not conducive, there needs to be understanding from parents so that students continue to study quietly even though they are studying at home.

On the statement that during online learning it is easier to understand the material explained by the lecturer, about 15 people answered that they did not agree. This indicates that face-to-face learning is irreplaceable, although lecturers continue to explain lecture material online either through zoom, gmeet, and others, their understanding will not be better than when learning in class. This statement is related to the previous statement regarding the understanding of the lecture material, due to the lack of understanding of the material, so that in carrying out the exams, both UTS and UAS have difficulty. 18 respondents answered that they did not agree that the UTS was very easy because they understood the material presented online. Lack of understanding of the material certainly has an impact on test results, Poor test results not only affect student grades, but also have an impact on the quality 
of the University. This is in accordance with what was conveyed by Dzalila et al (2020: 213), the decrease in GPA caused by a lack of understanding of the material can lead to a lower GPA of students, which also affects the quality of universities in Indonesia. So there is a need for additional learning outside of lecture hours to improve understanding of the lecture material.

In the next statement about the implementation of the practicum which is more enthusiastic when working independently than when in groups, about 13 people answered disagree, 9 people did not agree, meaning that the implementation of practicum which is usually carried out in groups must be carried out independently, lowering the spirit of the work. In addition to the implementation of independent practicum which reduces morale, about 17 respondents have difficulty in understanding the given practicum procedures. The results of the two statements indicate that the implementation of independent practicum is less effective to carry out. But because of the demands, like it or not, the practicum must be carried out even in the midst of a pandemic. Likewise, according to Saraswati, et al (2020: 145),

Around $46.7 \%$ of respondents answered agree and $16.7 \%$ of respondents answered strongly agree about the frequent network problems during online learning, thus reducing the spirit of learning. This shows that there are still many students who have network problems to participate in online learning which could be due to the location of their residence in an area that is difficult to network. According to Kusumaningrum (2020: 136), the difficulty of the network is a factor that makes it difficult for students to access online learning because they live in areas that are difficult to network, besides that bad weather factors can affect the network.

\section{Conclusion}

From the results and discussion, it can be concluded that (1) Biology education students admitted that there was a significant change in routine during the pandemic. These changes have an impact on student learning activities. (2) Most biology education students feel that they do not understand the material presented in online classes, this has an impact on their decreased enthusiasm for attending lectures. (3) Most of the biology education students are still constrained by the network in their respective areas. (4) Some students do not attend lectures or are late because they are not only studying, but also working and doing other activities. (5) In the religious aspect, during this pandemic, some students admitted that they were more punctual in praying.

\section{References}

Argaheni, Niken Bayu. 2020. Systematic Review: The Impact of Online Lectures During the Covid-19 Pandemic on Indonesian Students. Scientific Journal of Health and Its Applications. 8 (02). 99-108.

Brilianur, Dwi., et al. 2020. Analysis of Online Learning Effectiveness During the Covid-19 Pandemic. Journal of Elementary School Teacher Education. 1(2). 28-37.

Cahyani, Adhetya. et al. 2020. Learning Motivation of High School Students in Online Learning during the Covid-19 Pandemic. Journal of Islamic Education. 3 (01). 123140. 
Dzalila, Lizha, Q A., et al. 2020. The Effect of Online Learning During the Covid-19 Pandemic On The Level Of Student Understanding Of Learning. Signal Journal. 8 (2). 89-214.

Judge, Thursan. 2005. Learning Effectively. Jakara: Puspa Swara.

Haryanti, Devi, YP. 2020. Insomnia During the Covid-19 Pandemic. Scientific Journal of Health Sandi Husada. 12 (2). 1111-1116.

Jariyah, Ita Ainun., Tyastirin Esti. 2020. The Process and Obstacles of Learning Biology in the Covid-19 Pandemic Period: Analysis of Student Responses. Journal of Educational Science Research and Studies. 4 (2). 183-196.

Kusumaningrum, Betty., Wijayanto, Zainnur.2020. is Effective Online Mathematics Learning? (Case Study on Learning During the Covid-19 Pandemic Period). Journal of Innovative Creative Mathematics. 11 (2). 136-142.

Mardalis. (2008). Research Methods A Proposal Approach. Gamma media: Yogyakarta.

Moh. Nazir. (1998). Research methods. PT. Main Library Gramedia. Jakarta.

Nurhayat, Erlis. 2020. Improving Student Activity In Online Learning Through Quiziz Educational Game Media during the Prevention of the Spread of Covid-19. Journal of Pedagogy. 7 (03). 145-170.

Saraswati, Ni Luh PA, Mertayasa, I NK 2020. Practicum Learning Chemistry During the Coiv-19 Pandemic Qualitative Content Analysis Trends Utilization Online Technology. JournalMathematicsScience and The learning. 14 (2). 144-161.

Sari, Miss Kumala., et al. 2020. Strategies for Cultivating Islamic Character in Private MTS Students Al Manar Medan Johor (Case Study During Online Learning). Journal of Islamic Education. 1 (2). 147-164.

Singarimbun, Masri. (1994). Survey Research Methods. Jakarta: LPS3. 